|Conceptual Article / Derleme Makale |

International Students' Acculturation and Adjustment to College: Suggestions for Turkey

\title{
Uluslararası Öğrencilerin Kültürlenme Süreci ve Üniversiteye Uyumları: Türkiye İçin Öneriler
}

\section{Nesime Can ${ }^{1}$}

Keywords
1. Acculturation
2. International student
3. Adjustment to college
4. Orientation
5. Counseling

Anahtar Kelimeler

1. Kültürlenme

2. Uluslararası öğrenci

3. Üniversiteye uyum

4. Oryantasyon

5. Psikolojik danışma

Received/Başvuru Tarihi

27.04.2020

Accepted / Kabul Tarihi 03.09.2020

\begin{abstract}
In recent years, the number of international students has been increasing worldwide; thus, it is important to understand the difficulties that international students experience in their acculturation and adjustment to college processes. The support provided by developed and developing countries to international students in regard to college adjustment may differ from each other. Considering that colleges accept international students from around the world, especially in developing countries, the needs of these students should be well understood first, and then necessary support should attentively be provided to meet these needs. Therefore, the first purpose of this manuscript is to draw attention to the adjustment to college challenges of international students while explaining the concept of acculturation and emphasizing the relationship between international students' adjustment to college and acculturation processes. The second objective is to review studies conducted with international students in Turkey and to discuss some contradictory findings. Considering the adjustment needs of international students in Turkey, the final objective is to present practical suggestions for university policymakers, academics, advisors, as well as college employees working with international students such as counselors from university counseling centers.

Öz

Son yıllarda, uluslararası öğrencilerin sayıları dünya çapında giderek artmaktadır, bu sebeple de uluslararası öğrencilerin kültürlenme süreçleri ve üniversiteye uyumları konusunda yaşadıkları sıkıntıların anlaşılması önemlidir. Gelişmiş ve gelişmekte olan ülkelerin üniversiteye uyum konusunda uluslararası öğrencilere sağladığı destekler birbirinden farklı olabilir. Ancak ülkelerin kalkınma durumuna bakılmaksızın, üniversitelerin uluslararası öğrencileri kabul ettikleri göz önüne alındığında, kabul edilen bu öğrencilere gerekli desteği sağlamak için öncelikle bu öğrencilerin ihtiyaçları anlaşılmalı ve daha sonra da bu ihtiyaçları gidermeye yönelik destekler sunulmalıdır. Uluslararası öğrencilerin içinde bulunduğu uyum sürecine dikkat çekmek ve yaşanan sıkıntıların çözümü için öneriler sunmak için yazılmış bu derlemenin ilk amacı kültürlenme kavramını açıklayarak uluslararası öğrencilerin üniversiteye uyumları ile kültürlenme süreçleri arasındaki ilişkiyi vurgulamaktır. İkinci amacı ise, Türkiye'deki uluslararası öğrencilerle yapılan çalışmaları inceleyerek durum değerlendirmesi yapmak ve bazı çelişkili bulguları tartışmaktır. Son olarak da Türkiye'deki uluslararası öğrencilerin uyum ihtiyaçları ve gelişmiş ülkelerdeki üniversitelerin uluslararası öğrencilerine sağladığı destekler göz önünde bulundurularak, Türkiye'deki üniversite politika yapıcılarına, akademisyenlere, akademik danışmanlara ve uluslararası öğrencilerle doğrudan çalışan psikolojik danışmanlar gibi üniversite personeline yönelik uygulanabilir pratik öneriler sunmaktır.
\end{abstract}





\section{INTERNATIONAL STUDENTS' ACCULTURATION AND ADJUSTMENT TO COLLEGE: SUGGESTIONS FOR TURKEY}

In the past decade, there was a dramatic increase in the flow of international students in higher education around the world. According to the British Council Report (British Council, 2019), the United States of America (USA), the United Kingdom (UK) and Australia had the highest inbound mobility of international students; while China, Brazil and Mexico had the heaviest outbound mobility. When the mobility of students in Turkey is examined, the top five countries that students preferred to go for higher education can be listed as the USA, Germany, the UK, Bulgaria, and Austria (UNICEF, 2020). Comparing the inbound and outbound student mobility, the inbound number was much higher in Turkey. UNICEF (2020) reported that the Syrian Arab Republic, Azerbaijan, Turkmenistan, Iran Islam Republic, and Afghanistan were the top five countries that send international students to Turkey for higher education. Table 1 presents the current inbound and outbound numbers of students in Turkey.

Table 1. Inbound and Outbound Mobility of Students in Turkey

\begin{tabular}{llll}
\hline Country of Origin & Number of Students & Destination Country & Number of Students \\
\hline The Syrian Arab Republic & 15,042 & USA & 9,692 \\
Azerbaijan & 14,878 & Germany & 6,074 \\
Turkmenistan & 10,418 & United Kingdom & 3,101 \\
Iran Islamic Republic & 6,099 & Bulgaria & 2,614 \\
Afghanistan & 5,251 & Austria & 2,405 \\
\hline
\end{tabular}

Source: UNICEF (2020)

The Council of Higher Institution (CHI) provides yearly statistics of higher education in Turkey. According to the $\mathrm{CHI}$ report (2020), a total of 154,446 international students chose to study in Turkey during 2018-2019 academic year. Among these students, over 100,000 (64\%) were male and over 54.000 (36\%) were female. When the numbers were examined among the universities with the highest number of international students, the list was as follows; Anadolu University, Istanbul University, Karabuk University, Bursa Uludag University and Ondokuz Mayıs University. It is important to note that each of the listed institutions had over 5,000 international students during the 2018-2019 academic year (CHI, 2020). It is crucial to be aware of the numbers, motives, and needs of international students to provide quality support and education they need.

Researchers stated that the flow of students is usually from less developed countries to developed countries (Kondakci, 2011; Özoğlu, Gür, \& Coşkun, 2015). Based on the International Institute of Education (IIE) Open Doors report (IIE, 2019), over 1 million international students contributed $\$ 45$ billion to the USA economy by bringing funds from outside of the USA, while in Turkey, international students contributed around \$1 billion to the economy annually (Daily Sabah, 2019). To increase this source of economic activity, each destination country needs to better understand their current international student population characteristics, students' home cultures, needs, and ongoing adjustment experiences in the host country. To better conceptualize international students' adjustment issues, the concept of acculturation needs should be well understood first. Considering international and national data related to international students, this manuscript was developed with three main purposes. The first purpose was to provide an overview of the concept of acculturation and its relation to adjustment to college issues of international students. The second purpose was to review the literature to report research results which were conducted with international students in Turkey. The last purpose was to present practical implications for university policymakers, academics, advisors and counselors.

\section{Acculturation}

People travel around the world for different reasons, and they meet with other people with diverse backgrounds. Sam and Berry (2006) stated that "the meeting of cultures and the resulting changes are what collectively has come to be known as acculturation" (p.1). There has been an increased interest in acculturation (Chun, Organista, \& Marin, 2003) with two main reasons. The first one is the overall growth in worldwide migration, and the second reason is the rise in understanding the importance of the link between culture and human behavior (Berry, 2003; Trimble, 2003).

Acculturation was first used as a term in the late 19th century and it was defined from psychological, anthropological and sociological perspectives (Trimble, 2003). The process of acculturation was perceived as the result of long-term interaction between individuals from different cultures (Chun, Organista \& Marin, 2003). In this definition, long-term interaction requires continuity and change. The traditional explanation indicated that acculturation is cultural group progress with an achievable end, but more contemporary researchers emphasized that acculturation is not a linear progress. Berry (2003) and Sam and Berry (2006) stated that assimilation and acculturation were used interchangeably but there are some nuances on the interpretation of research findings. Therefore, the authors suggested that acculturation should be the preferred term.

Psychology is interested in individuals' behavior. At the group level, the changes might be taking place in the social structure of the group, while the individual level changes might be in identity, values, attitudes, and behaviors (Berry, 2003; Trimble, 2003). Therefore, researchers developed various models of acculturation, such as stress and coping model of acculturation (Berry, 1992), interactive acculturation model (Bourhis, Moise, Perreault, \& Senecal, 1997), affective-behavioral-cognitive model of acculturation 
(ABC; Masgoret \& Ward, 2006), and concordance model of acculturation (CMA; Piontkowski, Rohmann, \& Florack, 2002). Smith and Khawaja (2011) provided a comprehensive review of these models.

Among these models, stress and coping model of acculturation (Berry, 1992) and the ABC model of acculturation are the ones widely accepted and used. Berry's (2003) model of acculturation defines four different strategies of intercultural relations which are assimilation, integration, separation and marginalization. From the perspective of non-dominant cultural groups, when individuals do not want to maintain their cultural identity and seek daily interaction with other cultures, they use the assimilation strategy. In contrast, when individuals have a value on holding their original culture, and at the same time they want to avoid interaction with others, they use the separation alternative. When people are interested in maintaining their original culture while having daily interactions with other groups, they use the integration strategy. Finally, a marginalization strategy is used when there is a little possibility or interest in cultural maintenance and little interest in interaction with other people (Chun, Organista \& Marin, 2003; Saygın \& Hasta, 2018). These strategies are for non-dominant groups and individual members of these groups in a dominant culture. Yet, it is not always the case. Based on the definition of acculturation, it is clear that both non-dominant and dominant groups may become acculturated. When assimilation is sought by the non-dominant acculturating group, the process is defined as a melting pot, but when assimilation is demanded by the dominant group, it is called the pressure cooker. When separation is forced by the dominant group, it is called segregation, and when marginalization is imposed by the dominant group, it is called exclusion. Finally, when diversity is an objective of the society as a whole, the process of integration is defined as multiculturalism (Berry, 2003; Chun, Organista \& Marin, 2003)

The conceptualization of cultural and psychological acculturation has a multidimensional process (Chun, Organista \& Marin, 2003). The $A B C$ model of acculturation is a more contemporary approach and encompasses three concepts which are stress and coping, culture learning, and social identification (Masgoret \& Ward, 2006). According to this model, as life changes are stressful in nature, individuals are likely to experience stress in new cultures and tend to develop coping strategies for adjustment. Culture learning refers that individuals need to learn the new culture through social interactions and adapt culturally relevant social skills (Jindal-Snape \& Rienties, 2016; Masgoret \& Ward, 2006). Social identification asserts that individuals' cultural identity may change as a result of involving a new culture. With acknowledging the multidimensional process of acculturation, this model focuses on individuals' ability to adapt instead of environmental change.

\section{International Students as Sojourners}

There are various groups with different cultural backgrounds that are living together in plural societies. Sam \& Berry (2006) indicated that immigrants voluntarily move to some other places in order to have a better life. Refugees and asylum seekers (forced migrants) usually do not want to leave their home country, but push factors cause them to flee their homeland. While immigrants are mostly permanent participants, sojourners are temporary participants in their new society. For instance, international students just like diplomats and workers usually move into different cultures with the hesitation of becoming fully involved, because these individuals know that they will leave eventually (Anderson \& Guan, 2017; Pedersen, Neighbors, Larimer, \& Lee, 2011).

The term sojourner defines individuals who travel abroad to attain a goal for a limited amount of time; international students, tourists, expatriate workers, international civil servants, and military are some of the main sojourner groups (Pedersen et al., 2011; Sam \& Berry, 2006). Among these groups, the purpose of international students is to gain professional qualifications through education, and these students may stay for several months or years in the host country.

The adjustment of international students -sojourners- follows a U-shape curve with a four phase. At first, international students may experience euphoria, as they are fascinated by the new culture. However, this stage may not last long. Usually after six weeks of relocation, the culture shock phase starts (Rainoldi \& Gölzner, 2014). In this phase, individuals may start feeling frustration, loneliness, and anxiety (Oberg, 1960). This initial adjustment process to new culture is called culture shock (Oberg, 1960). At this stage, international students may also feel confused and overwhelmed by their lack of knowledge and understanding of the host culture (Oberg, 1960; Rainoldi \& Gölzner, 2014). The duration and intensity of this stage may vary depending on individuals' personality, perceived social support, and coping mechanisms. Additionally, culture shock may negatively affect individuals' physical and psychological well-being. Once the phase of culture shock ends, the acculturation phase starts. In this phase international students learn to deal with the new conditions and slowly adapt to the new culture (Rainoldi \& Gölzner, 2014). During the third stage, individuals need to be aware of their adaptation strategy (i.e. assimilation, integration, separation, and marginalization) and take necessary actions for a desired state of positive acculturation. The last phase of adjustment is called stable state. Based on the acquired adaptation strategy, individuals may feel discriminated against, assimilated or integrated to the new culture (Rainoldi \& Gölzner, 2014). Therefore, eventually, sojourners learn how to cope with difficult emotions, cultural differences and enjoy the stable state.

International students generally expect that they would stay in a different country or culture only for a limited period of time; therefore, these individuals tend to have online support from their family, friends in their homeland via phone or other social media resources (Li \& Peng, 2019; Yu, Foroudi, \& Gupta, 2019). Although a type of acculturation is necessary for these individuals, the knowledge of eventual return to their home country may cause fewer questions about changing identity or behaviors (Berry, Poortina, Breugelmans, Chasiotis, \& Sam, 2011). Additionally, most sojourners have a plan and preparation beforehand, and this preparation helps them to adjust easily. Although preparation and having a plan about the settlement are helpful, the degree and the quality of engagement with the host culture are more significant factors for international students' adjustment. Berry (2003)

| Kastamonu Education Journal, 2021, Vol. 29, No. 1| 
stated that international students' primary networks are individuals from the same culture. Next, these students socialize with other international students, and the third network includes the friends from host nations (Mrekajova, 2017; Pedersen et al., 2011). Thus, to ease the transition, it is wise for international students to seek help from friends to become knowledgeable about local customs and traditions.

\section{College Adjustment in a New Culture}

International students add diversity to a college and diversity brings different perspectives or problems to the table. Adjustment to college is a universal issue for many students, but some issues may create bigger problems for international students. It is important to acknowledge that international students deal with the same academic demands with their domestic peers in an unfamiliar environment with a lack of language skills (Gómez, Urzúa \& Glass, 2014).

Several researchers studied the concept of college adjustment (Gómez, Urzúa \& Glass, 2014; Watson \& Lenz, 2017; Wu, Garza, \& Guzman, 2015) and the model developed by Baker and Siryk (1984) was the one largely accepted. Their model consists of four dimensions which are academic adjustment, social adjustment, personal-emotional adjustment, and institutional adjustment. Academic adjustment is the degree to which students have adapted to the academic demands of their college (Lapoint \& Soysa, 2014). It includes students' attitudes towards their course of study, their engagement with material and their academic effort (Credé \& Niehorster, 2011). The social adjustment refers to students' integration into the social structures and communities of college, which includes attending campus activities, meeting with new people instead of experiencing loneliness or missing family members. Personal-emotional adjustment comprises students' psychological and psychical stress in order to respond to the demands of college. Finally, institutional adjustment refers to the level of students' emotional attachment to the college and college community (Baker \& Siryk, 1984; Credé \& Niehorster, 2011; Lapoint \& Soysa, 2014). Individuals need to practice all these four dimensions for college adjustment whether they are international or domestic students.

As mentioned above, college adjustment is a universal problem for many college students. Yet, international students experience similar college adjustment issues with their domestic peers during the process of acculturation in their new environment. The multidimensional acculturation process may cause feelings of isolation, confusion, frustration, and stress for international students (de Araujo, 2011). Dealing with college adjustment issues during the transitional stage complicates students' lives. Therefore, in today's diverse world, it is vital to enhance our knowledge of acculturation and college adjustment issues of international students so that we could better understand international students' needs and develop effective ways to support them.

\section{College Adjustment Issues Among International Students}

Numerous variables have an influence on international students' adjustment to college experiences (Lin, Peng, Kim, Kim, \& LaRosa, 2011; Wu, Garza, \& Guzman, 2015; Zhang \& Goodson, 2011). Students with various personalities from different cultures may need help for the adjustment process, as a result, it is important to be aware of these issues beforehand.

\section{Acculturative Stress}

International students encounter various life changes as a result of being in a different culture and these changes become stressors or hassles (Aliyev \& Ogulmus, 2016; Smith \& Khawaja, 2011). Acculturative stress is the emotional aspects of acculturation and it focuses on psychological well-being and life satisfaction (Berry et al, 2011). Smith \& Khawaja (2011) indicated that establishing a new social network is a sociocultural stressor for many international students. Moreover, financial problems such as tuition, accommodation, and transportation could be defined as practical stressors. Mori (2000) reported that acculturative stress could result in somatic complaints such as sleep and appetite disturbance, fatigue, and headaches. It might also lead to psychological symptoms such as isolation, helplessness, hopelessness, sadness, feeling of loss, anger, and disappointment. According to Smith \& Khawaja, (2011), acculturative stress was also associated with depression among international students.

\section{Language Proficiency}

Language proficiency is one of the most important variables related to college adjustment for international students. This competency is a continuing concern for many international students, and it affects individuals' levels of depression and anxiety. de Araujo (2011) reported that language fluency is a significant predictor of acculturative stress. Several researchers indicated that language is related with academic and social adjustment (de Araujo, 2011; Kang, 2006; Sümer, Poyrazli \& Grahame, 2008). Although academic stress can be an issue for all students, international students may experience academic stress at an intense level because of their language barrier (Smith \& Khawaja, 2011). Additionally, Sümer, Poyrazli and Grahame (2008) stated that international students with lower levels of language competency had higher levels of depression and anxiety in the USA. Kang (2006) also claimed that language competence was a stronger predictor of adjustment than the other domains of acculturation.

\section{Social Support}

Social support is an essential resource to cope with stress. Family, friends and faculty may provide support and assistance to contribute to international students' well-being. It was found that higher level of life stress and lower level of social support predict a higher level of academic stress among international students (Misra, Crist \& Burant, 2003). de Araujo (2011) reported that family and social support decrease the stress level of international students. Quan, Zhen, Yao, and Zhou (2014) found that loneliness had a negative impact on adjustment while suppressing positive coping styles. Although, establishing relationships with domestic peers was an important indicator of the international student's adjustment process, Sümer, Poyrazli and Grahame (2007) reported that 
international students' social interactions with domestic students were lacking. Similarly, Khoo et al. (1994) indicated that international students have less harmonious relationships with academic advisors, roommates and landlords compared to their domestic peers.

In addition to face to face support, recent technological innovations provide a new way of communication for international students. International students can easily communicate with their friends from their home country through technology. Ranney and Troop-Gordon (2012) addressed that lower levels of face-to-face friendship quality and computer-mediated communication with distant friends predicted lower levels of emotional distress. It means that adjustment depends on the quality of friendships and support, not the type of communication. Additionally, Eun-Ju, Lu, and Jeongwoo, (2011) reported that international students' internet use motivations are significant predictors of social and emotional adjustment. Specifically, students who seek to build a local network through the internet reported having greater satisfaction in their social life.

\section{Length of Stay in Abroad and Perceived Discrimination}

International students, who stay for more than six years in a host country, are likely to be more acculturated than individuals who stay less than six years (Sodowsky \& Plake, 1992). Additionally, it was found that the longer residence time in a host country was related to a lower level of psychological distress for international students (Wilton \& Constantine, 2003). During their sojourn, international students may experience various difficulties such as discrimination. Perceived discrimination is the interpretation of being subject to prejudicial treatment and for international students, it could be related to their ethnicity or regions of origin (de Araujo, 2011). It was reported that international students experience higher levels of discrimination than domestic students (Poyrazli \& Lopez, 2007). Additionally, Khoo et al. (1994) stated that international students experience racial discrimination mostly in public places like shops, buses, and dance halls.

\section{College Adjustment Among International Students in Turkey}

Many international students experience similar adjustment issues regardless of their host country. However, when we chose to examine college adjustment issues among international students in Turkey closely, findings can vary. For instance, Gündüz \& Alakbarov (2019) analyzed social adjustment factors of international students in Turkey and results suggested that communication with faculty members, utilizing counseling centers, and participating in social activities were found as substantial factors indicating social adjustment. Additionally, feeling safe was noted as one of the crucial factors of social adjustment among international students. Interestingly, language proficiency was not found to be a problematic issue. However, Cetinkaya-Yıldız, Cakır, and Kondakcı (2011) reported that life satisfaction, integration to social life, language proficiency, and length of stay in Turkey were reported as significant predictors of psychological stress. Therefore, there are conflicting findings in the literature.

Additionally, Alpaydın (2018) studied the educational experiences of international graduate students in Turkey and participants reported having problems with academic writing skills and receiving support during the orientation and adaptation process. Some participants mentioned having academic support with courses and thesis processes; however, others stated some concerns about course content which was designed for domestic students and overlooked international students' needs. In another study, researchers investigated factors to determine international students' overall satisfaction of their experience in Turkey and results indicated that quality of education, and administrative staff support were the top two significant factors on students' satisfaction (Uddin, Mamun, Soumana, \& Khan, 2017). Further, researchers stated that campus environment and safety, self-preparation, personal influence as recommendations given by family or friends were also found to be related to students' satisfaction. Participants in this study also reported having language proficiency as a challenge for adjustment (Uddin et al., 2017).

Özoğlu, Gür, and Coşkun (2015) studied factors influencing international students' choice to study in Turkey as well as challenges they experience, and results indicated that quality of education, affordability, scholarship opportunities were noted as factors influencing their choice. In this study, major challenges were also examined and the main challenge was reported as a lack of adequate guidance and information in regard to the pre- and post-arrival process (Özoğlu et al., 2015) which is consistent with Alpaydın (2018) findings. Acar (2016) investigated faculty perceptions of international students in Turkey and found that from faculty perspective, international students encountered challenges including; adjustment issues to the new educational system, language difficulties, time management issues, and isolation problems. In regard to friendship networks, Mrekajova (2017) conducted interviews with international students and found that these students prefer co-national friendship instead of making friends among domestic students. These results are also consistent with the literature (Berry, 2003; Sam \& Berry, 2006). Mrekajova (2017) stated that the lack of language proficiency and a cultural distance might be the reason for friendship preferences. Kağnıcı (2012) examined the role of multicultural personality in predicting university adjustment among international students and stated that social initiative, emotional stability, open-mindedness, and cultural empathy were significant predictors. Lastly, Elemo and Türküm (2019) conducted an 8-weekly psychoeducational intervention on adjustment, coping self-efficacy and psychological distress with international students in Turkey and results presented significant differences only in coping self-efficacy favoring the experiment group.

\section{Discussion and Implications}

The typical problems that international students face in their new culture can be discerned from their acculturation and issues of adjustment to college. Although each person is unique in using their coping skills to overcome adjustment challenges, having a greater understanding of transitional issues into a new culture may help individuals who work with international students directly. Here are some suggestions for higher education policymakers, academics, advisors, and college counselors in Turkey. 
First, colleges in Turkey may consider developing a well-rounded office for international students and work on enhancing and educating their staff, as Uddin and colleagues (2017) addressed the need. The office of international students is the first place where international students engage and interact with the university, so this interaction is vital for students' decision to come to Turkey. Bista and Foster (2011) stated that international students need information about the rules and regulations about visa application and travel policies, education system, course work, and college terminology in general. These students also need clear guidelines for transportation and accommodation. As Özoğlu et al. (2015) suggested, the office of international students should support individuals with their needs in both pre-and post-arrival processes. The staff can be educated with the adjustment, acculturation process, and ways to support these students when they need. The staff should also be assisting students with admission, registration, transportation, and financial aid concerns (Bista \& Foster, 2011). Especially the language proficiency issues can be resolved with some additional coursework, so the international students office may provide referrals to available language courses. Recent literature highlights the importance of social support among international students. Therefore, starting diverse student organizations and developing activities to create a diverse campus can also be helpful.

Furthermore, as Gündüz and Alakbarov (2019) stated, counseling centers may provide support for international students. Creating informative handouts for international students regarding to acculturation and college adjustment processes may help individuals to cope better with upcoming difficulties. Counselors working in these centers need to be educated about the factors including cultural diversity, acculturation, possible college adjustment challenges international students may encounter, and ways to support these students with practical issues, such as availability of cultural food and the opportunity to perform their religious practices (Khoo et al, 1994). Not only counselors but also faculty members should be sensitive to cultural differences and students' acculturation experiences because there is prevailing opinion as being too culturally sensitive which means attributing everything to cultural differences (Dean \& Koeng, 2019).

Cushner and Brislin (1996) noted that various cross-cultural training programs would help international students' adjustment process. Training about the host culture and role play on the potential problematic situations may prepare international students for potential challenges. It is important to remember that the office of international students and counseling center may work together to provide the best support. As an alternative to the psychoeducational interventions (e.g. Elemo and Türküm, 2019), some other suggestions can be taken into consideration. For instance, Lin and Yi (1996) provided program suggestions for prearrival adjustment, initial adjustment, on-going adjustment and returning to home adjustment. Each step has unique ideas to ease international students' adjustment issues. During the pre-arrival stage, the office of international students may share online information and tips to reduce stress, anxiety and prevent the possibility of culture shock. In the initial adjustment period, it is important to continue to orient students about campus, community, and educational system. Organizing a welcoming gathering and offering workshops about rules and regulations, cultures and traditions, financial planning, health care system, the banking system would be beneficial. During the on-going adjustment stage, offering workshops about stress management, time management, career development, and job hunting would be valuable. Right before international students returning to home, working with students to reduce their anxiety and creating an alumni organization to stay connected would benefit international students to complete their transition back to home.

Lastly, orientation programs for international students may provide different resources to help students with their adjustment. Coşkunserce and Bedir Erişti (2017) developed an online orientation system for international students' cultural adjustment process and found the system effective. Faculty members, academic advisors, and counselors may use both face to face and online opportunities to reach out to international students to inform them about the transition process, campus and community resources. Knowing that experiencing unhappiness, loneliness and frustration are normal reactions during the transition stage, students may find healthy ways to accept and cope with such difficult emotions. If counseling centers or office of international students could not provide emotional, psychological and practical support, then faculty members and academic advisors should make time for international students to discuss their academic concerns as well as their personal and social challenges.

\section{REFERENCES}

Acar, E. (2016). Faculty perception on international students in Turkey: Benefits and challenges. International Education Studies, 9(5), 1-11.

Aliyev, R. \& Ogulmus, S. (2016). An investigation of International Students' Acculturation Levels. Journal of Social Sciences of Muş Alparslan University, 4(1), 89-124)

Alpaydin, Y. (2018). Educational experiences of the international students in graduate programs in Turkey. Journal of Education and Learning, $7(2), 89-99$.

Anderson, J. R., \& Guan, Y. (2017). Implicit acculturation and the academic adjustment of Chinese student sojourners in Australia. Australian Psychologist, 53(5), 444-453. https://doi.org/10.1111/ap.12332

Baker, R. W., \& Siryk, B. (1984). Measuring adjustment to college. Journal of Counseling Psychology, 31, $179-189$.

Berry, J. W. (1992). Acculturation and adaptation in a new society. International Migration, 30, 69-85. https://doi.org/10.1111/j.14682435.1992.tb00776.x

Berry, J. W. (2003). Conceptual Approaches to Acculturation. In K.M. Chun, P.B. Organista, \& G. Marin (Eds.) Acculturation: Advances in Theory, Measurement, and Applied Research (pp. 17-39). Washington, DC: American Psychological Association. 
Berry, J. W., Poortina, Y. H., Breugelmans, S. M., Chasiotis, A. \& Sam, D. L. (2011). Cross-cultural psychology. Cambridge, UK: Cambridge University Press.

Bista, K. \& Foster, C. (2011). Issues of International Student Retention in America Higher Education. The International Journal of Research and Review, 7(2), 1-10.

Bourhis, R. Y. Moise, L.C., Perreault, S., \& Senecal, S. (1997). Towards and interactive acculturation model: A social psychological approach. International Journal of Psychology, 32(6), 369-386. https://doi.org/10.1080/002075997400629

British Council (2019) The shape of global higher education: International comparisons with Europe. Retrieved from https://www.britishcouncil.org/sites/default/files/k006_02_the_shape_of_global_higher_education_in_europe_final_v5_web.pdf

Chun, K. M., Organista, P. B. \& Marin, G. (2003). Acculturation. Washington, DC: American Psychological Association.

Coşkunserçe, O. ve Bedir Erişti, S. (2017). Uluslararasi öğrencilerin kültürel uyum sürecine yönelik tasarim tabanli araştirma yaklaşimina dayali çevrimiçi oryantasyon uygulamasinin geliştirilmesi. Eğitim Teknolojisi Kuram ve Uygulama, 7 (1), 83-104. DOI: 10.17943/etku.288489

Credé, M., \& Niehorster, S. (2011). Adjustment to college as measured by the student adaptation to college questionnaire: A quantitative review of its structure and relationships with correlates and consequences. Educational Psychology Review, 24(1), 133-165.

Cushner, K. \& Brislin, R. W. (1996). Intercultural interactions. California, U.S.A.: SAGE Publications.

Cetinkaya-Yildiz, E., Cakir, S. G., \& Kondakci, Y. (2011). Psychological distress among international students in Turkey. International Journal of Intercultural Relations, 35(5), 534-539. https://doi.org/10.1016/j.ijintrel.2011.04.001

Daily Sabah (2019). International students bring in over \$1 billion annually. Retrieved from https://www.dailysabah.com/economy/2019/10/18/international-students-bring-in-over-1-billion-annually

Dean, K., \& Koeng, A. M. (2019). Cross-cultural differences and similarities in attribution. Cross-Cultural Psychology, pp.575-597, John Wiley \& Sons Ltd.

de Araujo, A. A. (2011). Adjustment issues of international students enrolled in American colleges and universities: A review of the literature. Higher Education Studies, 1(1), 2-8.

Elemo, A. S., \& Türküm, A. S. (2019). The effects of psychoeducational intervention on the adjustment, coping self-efficacy and psychological distress levels of international students in Turkey. International Journal of Intercultural Relations, 70, 7-18.

Eun-Ju, L., Lu, L., \& Jeongwoo, J. (2011). Internet for the internationals: effects of internet use motivations on international students' college adjustment. Cyberpsychology, Behavior \& Social Networking, 14(7/8), 433-437.

Gómez, E., Urzúa, A., \& Glass, C. R. (2014). International student adjustment to college: social networks, acculturation, and leisure. Journal of Park \& Recreation Administration, 32(1), 7-25.

Gündüz, M., \& Alakbarov, N. (2019). Analysis of social adjustment factors of international students in Turkey. Journal of International Students, 9(4), 1155-1171. https://doi.org/10.32674/jis.v9i4.917.

International Institute of Education. (2019). Open doors 2019. Retrieved from https://www.iie.org/Research-and-Insights/Open-Doors/Data Jindal-Snape, D. \& Rienties, B. (2016). Multidimensional Transitions of International Students to Higher Education. Routledge

Kang, S. (2006). Measurement of acculturation, scale formats, and language competence. Journal of Cross-Cultural Psychology, $37(6), 669$.

Kağnıcı, D. Y. (2012). The role of multicultural personality in predicting university adjustment of international students in Turkey. International Journal for the Advancement of Counselling, 34(2), 174. https://doi.org/10.1007/s10447-012-9149-5

Kondakci, Y. (2011). Student mobility reviewed: Attraction and satisfaction of international students in Turkey. Higher Education, $62(5), 573$.

Khoo, P. L. S., Abu-rasain, M. H. \& Hornby, G. (1994) Counselling foreign students: A review of strategies, Counselling Psychology Quarterly, 7(2), 117-131.

Lapoint, S. O., \& Soysa, C. K. (2014). Great Expectations: Perfectionism and Residence Status Predict College Adjustment. Psi Chi Journal of Psychological Research, 19(3), 98-107.

Li, L., \& Peng, W. (2019). Transitioning through social media: International students' SNS use, perceived social support, and acculturative stress. Computers in Human Behavior, 98, 69-79. https://doi.org/10.1016/j.chb.2019.03.011

Lin, J-C., \& Yi, J. K. (1996). Asian international students' adjustment: Issues and program suggestions. College Student Journal, $31,71-78$.

Lin, J., Peng, W., Kim, M., Kim, S. Y., \& LaRose, R. (2011). Social networking and adjustments among international students. New Media \& Society, 14(3), 421-440. https://doi.org/10.1177/1461444811418627

Masgoret, A., \& Ward, C. (2006). Culture learning approach to acculturation. In D. Sam \& J. Berry (Eds.), The Cambridge Handbook of Acculturation Psychology (Cambridge Handbooks in Psychology, pp. 58-77). Cambridge: Cambridge University Press.

Misra, R., Crist, M., \& Burant, C. J. (2003). Relationships among life stress, social support, academic stressors, and reactions to stressors of international students in the United States. International Journal of Stress Management, 10(2), 137-157.

Mori, S. (2000). Addressing the mental health concerns of international students. Journal of Counseling \& Development, 78(2), $137-144$.

Mrekajova, E. (2017). Friendship networks of international students attending long-term programs in turkey: Implications and a need for intervention. International Journal of Contemporary Educational Research, 4(2), 26-38.

Oberg, K. (1960). Cultural Shock: Adjustment to New Cultural Environments. Missiology: An International Review, 7(4), $177-182$. https://doi.org/10.1177/009182966000700405

Özoglu, M., Gür, B. S., \& Coskun, I. (2015). Factors influencing international students' choice to study in turkey and challenges they experience in Turkey. Research in Comparative and International Education, 10(2), 223-237. 
Pedersen, E. R., Neighbors, C., Larimer, M. E., \& Lee, C. M. (2011). Measuring sojourner adjustment among American students studying abroad. International Journal of Intercultural Relations, 35(6), 881-889. https://doi.org/10.1016/j.ijintrel.2011.06.003

Piontkowski, U., Rohmann, A. \& Florack, A. (2002). Concordance of acculturation attitudes and perceived threat. Group Processes \& Intergroup Relations, 5, 221-232. https://doi.org/10.1177/1368430202005003003

Poyrazli, S., \& Lopez, M. D. (2007). An exploratory study of perceived discrimination and homesickness: a comparison of international students and American students. Journal of Psychology, 141(3), 263-280.

Quan, L., Zhen, R., Yao, B., \& Zhou, X. (2014). The effects of loneliness and coping style on academic adjustment among college freshmen. Social Behavior and Personality, 42(6), 969-978.

Rainoldi M., Gölzner H. (2014) Mentoring across cultures: Implications in managing expatriates' acculturation. In: Stumpf M., Wehmeier S. (eds) Kommunikation in Change und Risk. Europäische Kulturen in der Wirtschaftskommunikation, vol 18. Springer VS, Wiesbaden

Ranney, J. D., \& Troop-Gordon, W. (2012). Computer-mediated communication with distant friends: Relations with adjustment during students' first semester in college. Journal of Educational Psychology, 104(3), 848-861.

Sam, D. L. \& Berry, J.W. (2006). Acculturation psychology. Cambridge, UK: Cambridge University Press.

Saygın, S., \& Hasta, D. (2018). Göç, Kültürleşme ve Uyum. Current Approaches in Psychiatry / Psikiyatride Guncel Yaklasimlar, 10(3), 302-323. https://doi.org/10.18863/pgy.364115

Smith, R., \& Khawaja, N. (2011). A review of the acculturation experiences of international students. International Journal of Intercultura Relations, 35(6), 699-713.

Sodowsky, G. R., \& Plake, B. S. (1992). A study of acculturation differences among international people and suggestions for sensitivity to withingroup differences. Journal of Counseling \& Development, 71, 53-59.

Sümer, S., Poyrazli, S., \& Grahame, K. (2008). Predictors of depression and anxiety among international students. Journal of Counseling \& Development, 86(4), 429-437.

The Council of Higher Institution. (2020). Retrieved from https://istatistik.yok.gov.tr/

Trimble, J. E. (2003). Introduction: Social change and acculturation. In K.M. Chun, P.B. Organista, \& G. Marin (Eds.) Acculturation: Advances in Theory, Measurement, and Applied Research (pp. 17-39). Washington, DC: American Psychological Association.

Uddin, M., R., Mamun, A., Soumana, A., O., \& Khan, M. (2017). Factors and Predictors of International Student's Satisfaction in Turkey. Educational Process: International Journal, 6(2), 43-52. https://doi.org/10.22521/edupij.2017.62.4

UNICEF (2020). Global Flow of Tertiary-Level Students. Retrieved from http://uis.unesco.org/en/uis-student-flow

Watson, J. C., \& Lenz, A. S. (2018). Development and evaluation of the inventory of new college student adjustment. Journal of College Student Retention: Research, Theory and Practice, 0, 1-16. https://doi.org/10.1177/1521025118759755

Wilton, L., \& Constantine, M. G. (2003). Length of residence, cultural adjustment difficulties, and psychological distress symptoms in Asian and Latin America international college students. Journal of College Counseling, 6(2), 177-186.

Wu, H., Garza, E., \& Guzman, N. (2015). International Student's Challenge and Adjustment to College. Education Research International, 1-9. https://doi.org/10.1155/2015/202753

Yu, Q., Foroudi, P., \& Gupta, S. (2019). Far apart yet close by: Social media and acculturation among international students in the UK. Technological Forecasting \& Social Change, 145, 493-502.

Zhang, J. \& Goodson, P. (2011). Predictors of international students' psychosocial adjustment to life in the United States: A systematic review. International Journal of Intercultural Relations, 35(2), 139-162. https://doi.org/10.1016/j.ijintrel.2010.11.011 